\title{
Education, Experience and Profits: An Application for the Job of Non Wage-earners
}

\author{
Simon Alain Song Ntamack (Assistant Lecturer) \\ Faculty of Economics and Management, University of Yaoundé II \\ P.O Box 1365/25069, Yaoundé, Cameroon \\ Tel: 237-9999-1350 E-mail:songntamack@yahoo.fr.
}

Received: November 14, 2011

Accepted: January 5, 2012 Published: February 16, 2012

doi:10.5539/ijbm.v7n4p57

URL: http://dx.doi.org/10.5539/ijbm.v7n4p57

\begin{abstract}
The aim of this study is to justify the human capital theory in the explanation of the differences within work benefits for non wage-earners in Cameroon. This process is extremely rare in labor economics, since individuals are generally considered to be salaried. This study uses a theoretical framework developed by Mincer (1974) to model logarithmic earnings as determined by both the economic and noneconomic individual characteristics. The data are collected from the National Institute of Statistics' 2005 Employment and the Informal Sector Survey (EISS) which give information from 8.540 households around t0he country. The results show that education and experience play a crucial role in profits of work determination for non wage-earners likewise usual working condition.
\end{abstract}

Keywords: Human capital, Education, Experience, Non wage-earner, Profit

\section{Introduction}

The relationship between education, professional experience and the pay package has interested economists for a long time now. From the contribution of theoretical and empirical works which have been carried out, the human capital theory (Becker, 1964; Mincer, 1974; Willis, 1986), which is one of the simplest and most completed, postulates that accumulated experiences determine the individual's capacity to produce, his/her ability to exercise functions and get remuneration. This latter perceived at each period of life is interpreted as the returns of the personal investments undertaken before at school, as well as during the first years of work.

The continuation of studies thus implies that efforts and sacrifices are authorized, insofar as the anticipated impact on future benefits is satisfactory. By improving labor factor qualities, thus its productivity, "human capital" makes it possible to explain part of the "residue" of unexplained growth (Lemelin, 1998). Individuals then choose at the same time their level of training and expected benefits. However, more extensive surveys of work-related learning threaten to undermine learning organization revisions of human capital theory entirely, by exposing the lack of sustained relations between continued learning and earning for most workers (Livingstone, 1997). We can then admit in order to complete our initial analysis that, professional experience also enriches human capital, thus it is accompanied by a real increase in working benefits.

Human capital theory makes it possible to give an orientation to the revenue distribution at work such as the "benefits functions" which can give a synthetic view. It also permits to predict the way future flows in remunerations as should be structured during an individual's active life. However, it's a subject to many criticisms, particularly in a strict economic point of view which retains the idea of individual arbitrations, but also to the supposed effectiveness from years of formal school attendance.

So doing, competitive analyses were developed in school as an essential role "detection" and "selection" of individuals according to their aptitudes (Arrow, 1973; Spence, 1974). Indeed, school in itself would hardly improve the productive capacities of future workers. Its role would be restricted to certify individual capacities and also classify them amongst others. Within other important limit, the human capital theory poorly explains the diversity of remuneration practices within enterprises. It neither integrates the important role of institutions and conventions which govern the labor market, nor do the consequences of recent upheavals which put in doubt the logic of paid employment.

In fact since the early 1970s, non wage-earners have collectively asserted themselves especially in developing 
countries, with the rise of informal economy (Pagès, 2008; Hirata, et al., 1998). They represent today more than $80 \%$ of the active population in the world as part of the new mechanisms of income distribution (Gazier, 1992; Fields, 2007). Such a situation brings out the problem to know the determinants of income (Note 1) activity of the non wage-earners, which alone has an indisputable importance. Indeed, their standard of living depends on the amount of wages that they draw from their activity.

The objective of this paper is to justify the pertinence of human capital theory in explaining the differences within benefits of work for non wage-earners, through a simple empirical relationship which only takes into account the Length of studies and professional experience. These stakes find a significant echoe on both political decision makers and isolated agents. The necessity of disposing of a minimum stock of human capital to ensure better perspectives while favoring individual wellbeing constitutes the heart of a strategy defined by the Millennium Development Goals (MDG), put in place by United Nations, aiming at alleviating extreme poverty. To test the robustness and the relevance of this relationship, some current mechanisms will complete the specifications of human capital, taking into consideration the heterogeneity within a more or less successful year of schooling or a more or less transferable professional experience. Also, after presenting the model used, an explanation of data and variables will precede the development of the results as well as the recommendations of the study.

\section{The model and method}

Considering that workers are remunerated on the base of their marginal productivity, and that this increases with the level of education and experience, the human capital provides a methodology which permits to estimate increases in individual revenues resulting from an additional year of school. Generally, to determine de rate of return from a certain number $S$ of school years, Mincer (1974) estimate an equation of the following:

$$
\ln Y=a+\alpha S+\beta_{1} E+\beta_{2} E^{2}+\varepsilon
$$

With: $Y$ individual income of the worker, $E$ the professional experience, $a$ the constant, and $\varepsilon_{i}$ a stochastic term representing the non observed factors affecting the revenue, and considered as null average factors, which are not inevitably known by the individuals. In this semi-logarithmic profit equation, if $\varepsilon$ is distributed according to standard properties, then the estimated $\alpha$ by Least Squares (OLS) method corresponds to the return on education. However it is necessary to admit this estimation in bias due to the density of the problems that it generates.

For example, it is natural to suppose that environmental conditions do influence the economic value of individual investments in human capital. It is particularly the case with parental education or living conditions which have positive impact on the cognitive development of children, the quality of the education which they receive and on their academic success. Also educated parents worry about offering to their children a social capital, which will eventually permit them to aspire for more valued jobs in terms of position and remuneration for any given period of education. The social environment then has a direct effect on individual revenue and an indirect effect following his level of education.

Moreover, the working conditions can bias substantially the returns on education. The group of theories haven analyzed the positive impact of education on the distribution activity income affirms that education emits externalities on growth and on many other economic indicators of development (Card, 2001). The point of disagreement between these theories is generally observed in the sense that should be given to this correlation. Horeover, assuming that the relationship between activity revenue and accumulated human capital is linear, brings us to thinks that exogenous chocks like demand and supply of jobs have the same effects on the rate of return on education at all the levels. This hypothesis is criticized by Heckman and al. (1996), who thinks that the school Length is not homogeneous, and every hours of work do not have the same efficacy. In order to admit that the return on education and experience varies with the volume of educational investments, it is preferable to integrate level of education in a quadratic form. Taking into consideration such phenomenon, the Mincer's extend model is here by written as:

$$
\ln Y_{i}=a+\alpha_{1} S+\alpha_{2} S^{2}+\beta_{1} E+\beta_{2} E^{2}+\beta_{3} X_{i}+\varepsilon_{1 i}
$$

with $X_{i}$ as a factor representing individual and environmental characteristics. However, this extension can also give place to other problems. On one hand, activity income of individual $i$ is observed if and only if it is higher than an alternative income. This does not suppose that the non wage-earners constitute a random sample of the working population as a whole. Conversely, it is possible to think that non wage-earners as well as employees 
are subjects to particular characteristics. The education's rate of return could possibly find itself affected so; estimation using observed revenues have to take into account censures to the left of the sample as demonstrated by Heckman $(1976 ; 1979)$.

In order to correct the bias of selective participation in the labor market, it would be necessary to consider a probabilistic model inspired by Bourguignon and al. (2007), following the correction procedure of this bias based on the conditional mean $\varepsilon_{i}$ from the generalization of Heckman's (1979) model. The decision of participation comprises several options amongst which the individual must necessarily make a choice, the interpretation of this variable consists in seeing through it a measurement of the propensity to choose one of the options: to be non wage-earners, to be paid, to be unemployed, and to retain the alternative which maximizes it utility in terms of profit. By so doing, an evaluation obtains potential profits or more precisely, unobserved productivity of each individual, including those who perceive a different form of remuneration.

In addition, estimation of equation (2) by the OLS method is only corrected if explanatory variables are not correlated with unobserved factors. Most often, more intrinsic individuals' facilities are more likely to follow longer studies but also to receive higher incomes. In this case, their supplementary income will be attributed wrongly to their supplement of education. One speaks then of endogenous bias as the origin of an over-estimate of educational yields. To correct the skew, the most frequent adopted solution consists in following Gourieroux (1989, page 197 (Note 2)), to correctly use the variable $S_{i}$ and its square trough the method of Two-Training course Least Squares (2SLS).

Finally, the model thus takes the form of a system with three equations:

$$
\begin{gathered}
R_{i}=b_{1} Z_{2 i}+\varepsilon_{3 i} \\
S_{i}=c Z_{1 i}+\varepsilon_{2 i} \\
\ln Y_{i}=a+\alpha_{1} S+\alpha_{2} S^{2}+\beta_{1} E+\beta_{2} E^{2}+\beta_{3} X_{i}+\beta_{4} \phi_{i}+\varepsilon_{1 i}
\end{gathered}
$$

With $\mathrm{R}_{\mathrm{i}}$ which indicates the probability for the individual $i$ in taking part in the labor market and non wage-earning job, to be estimated by a multivariate logit (Note 3) model, $Z_{1 \mathrm{i}}$ and $Z_{2 \mathrm{i}}$ vectors of regressions, and $\left(\phi_{i}\right)$, the reverse Mills ratio calculated starting from equation (3). The estimated value of $\left(\phi_{i}\right)$ makes it possible to explain its sign. Thus, when this value is significant, it implies that there is a skew of selection and that the OLS method will produce strong skewed results. The human capital theory allows an interpretation of the parameter $\phi_{i}$ as being the human capital "unobserved" which permit individual $i$ to overcome all the risks and requirements which are imposed to him by the operation of the working relationships.

\section{Data}

The principal data source used here comes from the data base of a priority investigation, carried out by the National Institute of Statistics in 2005. It is all about a national survey carried out in 8536 households having as base, a survey laminated in two degrees towards national households' surveys ECAM 1 and 2. The Employment and informal Sector survey (EISS) delivers a very precise data particularly relating to the professional status, the schedules of work and the monthly incomes of net activity of the agents.

The definition and the summary of the variables used to evaluate the influence of the human capital in the formation of activity incomes of non wage-earners appear in table (1). The detailed description of these variables makes it possible to use the transformations undergone by some of them, particularly the passage from the multiple dummy variables to dichotomist dummy ones. All these variables concern particularly the socio-demographic context (age, matrimonial status, size of the household), the human capital (seized by the Length of the studies and seniority), the level of benefits of work (seized by the neperian logarithm of the monthly activity' income), and the socio-economic environment.

This is then how unmarried and married, respectively within the framework of the matrimonial status, mean that the individual is unmarried or married. A non wage-earner can generally carry on his lucrative activity in the littoral (Douala, administrative headquarters of the Littoral and South-west), the forest (Yaounde, the administrative headquarters of the Center, South and East), the western highlands (West and the North-West) or finally in the Sahel (Adamaoua, Far-north, North). Religious distinctions clearly separate the Christians, mainly represented in the sample, from all the other religions (Muslim, Animist etc). To justify these variables, it is good to note that age plays a significant role in the education and continuation. An advanced age for example can appear to be counterproductive because of the profitability of the investment in time. Variables that arise from human capital make it possible to show that the longer the training, the better activity incomes. This is being backed by the general knowledge acquired during school, or by know-how acquired on the field. 
The statistical description of variables used to bring forth the impact of human capital in the determination of activity incomes of non wage-earners appears in table (2). The innovation drawn from this description shows that non wage-earners in Cameroun perceive an average income strongly dispersed around 2.80. To reach such a level of profit, non wage-earners must have undergone approximately, a five years initial training with a specific one acquired on the bundle activities which are usually leads. Thus, for a relatively young population (35 years on average), non wage-earners need to justify at least nine years of working experience. Taking into account the strong disparities which characterize these two variables brings us to conclude that they fit more or less quickly in the labor market.

The modal class of level of education regroups non wage-earners who have a primary educational level; more than $65 \%$ of them have hardly completed their studies at this level. Using these statistics, it appears that accumulation of human capital by the non wage-earners rests mainly on the training system. For indeed, the Length of studies are so weak that self-tuition through experience and know-how acquired play an undeniable role.

As a whole, the statistical data make it possible to note that the non wage-earning activities are mostly practiced in urban environment $(70.66 \%)$ in a more or less stable distribution of the four regional regroupings. The major part of non wage-earners are female (55.39\%), not yet married (50.7\%), practicing Christian religion (71.9\%) and do not have practically any physical handicap which can prevent them from working. Lastly, many of them have a social life within a relatively harmonious environment where the father/partner, sometime legal guardian and head of family had a remunerated employment (77.49\%) which did not prevent his daily presence in the household and education of children.

\section{The results and recommendations}

The table (3) presents equations of incomes resulting from the standard model of Mincer (equation (1)), as well as its corrected form (equation (5)). The reading of the results which rises from these two relations shows that education as much as the cumulated experience, always have a positive and statistically significant effect on the activity' incomes of the non wage-earners.

In Mincer's standard equation, the yield of education reaches the threshold of $7 \%$. One additional year of studies would thus generate for the non wage-earning workers a relative increase of seven points in terms of percentage on their activity income. Every non wage-earner's productivity has an increasing function to the level of individual competence, i.e. of its human capital. Education thus makes it possible for the non wage-earning persons to accumulate competences (human capital), who's output turns to result in higher remunerations. Similarly the influence of the professional experience on non wage-earners' activity incomes is statistically and significantly positive.

Everything being equal, the human capital theory permits us to understand the fact that the differences in capital are related, that the differences in productivity result from the differences in investment trainings. However, investments on human capital being related to the family and sociological environments, it's appropriate to delay somehow on the explanation of participating in the labor market.

By estimating the probability of working, (appendix) the level of education and other instrumental variables influence significantly the probability of working while being a non wage-earner. Logically, most educated (better educated) individuals are also the least expected to exercise non wage-earning professions. Everything being equal, those having an education at least equal to the secondary level participates less in the labor market if they are to be non wage-earners as compared to those having a more inferior level of education. The weight of education here by seems to constitute a significant determinant of the probability of working while being a wage-earner.

The significant value of Mill's inverse ratio $\left(\phi_{i}\right)$ translates the existence of selection bias during the assignment of individuals in the labor market. This inverse ratio presented in the equation of labor revenue has as objective to take into consideration potential bias selections. The observed significance of this ratio implicitly justifies the adoptions of estimation models which corrects or adjusts the selection biases. Thus the selection of individuals in the labor market and their reallocation towards the status of non wage-earners appears to be significantly and statistically nonrandom. It also follows that the unobserved characteristics which positively influences the probability of being non wage-earners on the labor market, explains also the probability for them to obtain a consequent remuneration. Moreover, the correction of selection bias modifies the significance of so many explanatory variables such as the period of education (length) and experience in the work they execute, which definitely reinforces the point of human capital in the determination of revenues. Non wage-earners can now boast of a level of revenue (activity revenue) superior to the average one of the working age population (positive 
sign of the Mill's inverse ratio $\left.\left(\phi_{i}\right)\right)$ if more to that they possess the same characteristics.

Parallel to the corrected income equation, the endogeneity of the length of studies and its square, are checked respectively by a threshold of 10 and 1\% according to Hausmans' test (1978). The double square method does not only provide convergent estimators but also contributes to ameliorate sensibly the explicative capacity of the profit model (adjusted $\mathrm{R}^{2}$ (Note 4 ) move from $10.74 \%$ in the standard model to $15.75 \%$ ). This sensible improvement in the explanatory capacity of the model comes from the importance that the human capital has in the determination of non wage-earners incomes. This thus influences on the participation in the labor market and equally on workers remunerations. Let's note that the value of the coefficient of determination is in accordance with literature on this subject (Cahuc and Zylberberg, 2003). This weak or low value does not put into doubt the model; but reflects a great heterogeneity of the individual's activity income.

The importance of human capital in the formation of activity income of non wage-earning persons can consequently appreciate before and during the active life. In addition, the Length of studies has significant and statistical boosting effects on non wage-earner's activity income. The positive coefficient of the rate of return of an additional year of study indicates therefore that workers perceive higher incomes when they had been educated. This results confirms all works which recognized the importance of human capital in the distribution of activity incomes (Mincer, 1974), in particular those carried out on Cameroonian data (Abessolo, 1997; Ajab-Amin and Awung, 2005; fomba, 2008). However they contrast with the works of Tafah-Edokat (1998) in Cameroon and in general with those of Psacharopoulos (1994) in the case of a world analysis

The basic idea of the human capital theory assumes that the more the expenditures in training, the higher returns in terms of benefits or yields will be. Hence if the productivity of any employment grows with function to the level of competence of the worker, this one can then be assimilated as the human capital detained by the individual. The activity income of non wage-earners practically depends on initial trainings acquired with a given level of qualification. Non wage-earners can consequently discount high activity incomes. Taking into account the cost (Note 5) of training in this analysis makes it possible to attach profits resulting from a better education to the important returns on investments. From these perspectives, well trained non wage-earning workers have greatest effectiveness, as their activity income is closely related to productivity. However this causal sequence of Education-Return preached by the traditional human capital theory caused a number of controversies which questions the role of education (Arrow, 1973; Spence, 1973; Thurow, 1975).

The observation of the causal relation between the level of education and the activities incomes of non wage-earners as described by equation (1) and (5), does not necessarily confirm the existence of a causal relation. According to the signal theory developed by Spence (1973), education plays the role of a filter used in selecting workers with innate effectiveness. The training system therefore permits to signal or identify productive characteristics of workers which would not have been observed otherwise. In this logic, the diploma is an essential and easy indicator. In concrete cases, the correlation between level of human capital and activity incomes comes from the fact that most effective individuals have better returns and are trained longer, without education necessarily contributing to improve their individual productivity. In fact as to what concerns non wage-earners, the emitted signal seems to reveal their effective production capacity. The fact of working on their own account constitutes a powerful tool of evaluation of production capacities since income depends directly on it. Yields in work of non wage-earners are indeed tributary to concrete professional results and in addition to the individually undergone risks.

Education (Note 6) is not the only factor which guarantees the acquisition of capacities Mincer (1993) stresses on the continuation of investment by assuming that individuals acquire production capacities even after formal education, professional experience being a significant source of acquiring competences. In some sense, it's appears that substantial informal learning is essential to master a job (Livingstone, 1997).Thus for a non wage-earner, each additional year of experience capitalized in work gives rise to an increase in activity income of about $1.67 \%$. The quadratic form which represents the concavity of the profit profile shows that outputs are decreasing with experience.

There would thus be a significant relation between experience and activity income of non wage-earners. The variation of income on activities with the seniority at work and the concave configuration suggest that the investments are higher in the beginning of a career and less intense later on. Nevertheless, compared to education, these investments are not directly observed. Only profit profiles can be observed and qualified. However, the positive impact of seniority at work on the activity income varies in a continuous way translating the fact that for the non wage-earners, it takes time to settle on a market and to realize it first profits (benefits).

Parallel to experience, the Age-Profit profile presents a bell like shape since the negative coefficient of the 
squared age is significant. Generally, experience is especially useful at the beginning of careers and as soon as it is well accumulated, any additional year of experience is less remunerative. Although such a result has been checked on non wage-earners (Gindling 1991) this results can be considered as counterproductive. In fact as underlined by Smith and Metzger (1998) in their study on informal sector, the weak opportunities of progressing presented to non wage-earners instead allow us to assume an Age-profit profile which is relatively flat in nature. The contrasting effects of age and profit come from the fact that accumulated human capital by non wage-earners is basically specific. Job training appears to be the principal mechanism of acquisition of competence leading to a better productivity and higher gains.

The accordance on profiles reinforces the relatively significant weight of schooling and experience in the determination of non wage-earners' incomes. The level of human capital acquired in school (initial training) and that capital acquired with seniority translates a continuous effect on activity income of non wage-earners' incomes. The human capital theory thus appears to be significant in explaining the deviations within activity incomes of non wage-earners. In fact the deviation in qualifications within them plays an important role, and the inequalities of working productivities are being the inevitable factors to explain the phenomenon. Activity incomes of non wage-earners are very dependent of the characteristic of accumulated human capital. Remuneration in particular is an increasing function of the level of education, and experience shows that even in the absence of formal remunerations reparation, the human capital is likely to be appreciated in non wage-earning activities. These results are in conformity with those of ECAM 2's investigations which trace the importance of education as well as experience in the valorization of the human capital and poverty alleviation. However the analysis leaves us to think that the individual experience acquired by practical know-how give more convincing results in terms of benefits than formal education.

However, it should be noted that these results do not take into consideration the possible skews caused by unobserved individuals heterogeneity. If certain characteristics can positively influence individual productivities on non wage-earners, these results are likely to underestimate the impact exogenic parameters on the activity income. In the same way, the use of cross-sectional data as it's the case in several works which could induce skews related to the existence of unobserved variables (Brown 1980). In this order of ideas, remuneration of non wage-earners should be broken into a sum effects related to the accumulation of competences which may be appraised by individuals, but also to a certain extend to the unobserved heterogeneous individual characteristics.

\section{Concluding remarks}

The objective of this paper was to question the aptitude of human capital to effectively take part in the determination of non wage-earners' activity income. The particularity of human capital completely implicates the individual who carries it out. Also, its personalization, its limitations and its incorporation into the person make all the decisions concerning its allocation to be taken naturally, influencing the formation of incomes.

The meticulous examination of the relation which binds returns on activity to the human capital, and particularly the role of education and experience at work make it possible to know a certain number of considerations. On one hand, the constitution of human capital presents a certain numbers of specificities like its incorporation to the individuals, its acquisition not being done without cost. Consequently, if human capital is regarded as an investment, the behavior of maximization consists in comparing the absent value of the anticipated profit at the capital cost of human capital. In addition, the heterogeneity of individual's investments in human capital influences the formation of activity incomes. If models make it possible to characterize in a rigorous way the income profile in time, the empirical application is not always obvious. However, the economic theory has synergized theoretical rigor and empirical application by the derivation of an investment effect of human capital on activity income.

On the basis of employment data and the informal sector survey (EISS, 2005), the paper cleared some premises thereafter by examining the output of education and experience since the educational investment, just like all investments, can be evaluated in terms of yields. The analysis corrects the skew of participation in the labor market and the selection of the status of employment according to a procedure which instruments the level of education, presumably endogenous with the activity income.

The yield of an additional year of study reaches $7.6 \%$ and proves to be robust with the various specifications of the model. If the Length of the studies influences the remuneration of the non wage-earners, the effectiveness is marked even when a worker of a relative seniority at work. Indeed, each additional year of experience is suitable to increase the monthly activity income by about $1.67 \%$. The activity income of the non wage-earners thus combines with specific know-how acquired by experience or informal education, general knowledge acquired by formal education. The correlation between the level of human capital and activity income has permitted to note 
that the most effective individuals have indeed the best returns and are trained longer. Also, the accumulation of knowledge by the non wage-earners does not correspond solely to the emission of a signal, but it contributes indeed to increase their individual productivities and consequently their profits.

Finally, the whole result clarifies the significant effect of the human capital on the individual incomes of the non wage-earning persons whatever the case, the concept of yield of education presents a certain number of limits which are necessary to keep in mind in order to prevent that the results obtained are skewed.

\section{References}

Abessolo, Y. A. (1997). Capital humain, salaires et segmentation du marché du travail en économie sous-développée: le cas du Cameroun. Thèse nouveau régime en Economie. Bordeaux 4: Faculté des sciences économiques et de gestion.

Ajab-Amin, A., \& Awung, W. J. (2005). Economic analysis of private returns to investment in education in Cameroon. Regional conference on education in West Africa: constraints and opportunities, organized by Cornell/CREA/INRA/Ministry of Education. Dakar-Senegal: November 25-26.

Arrow, K. (1973). Higher Education as a Filter. Journal of Public Economics, 2(3), 193-216. http://dx.doi.org/10.1016/0047-2727(73)90013-3

Bardhan, P., \& Udry, C. (1999). Developments microeconomics. Oxford: Oxford University Press. http://dx.doi.org/10.1093/0198773714.001.0001

Becker, G. S. (1964). Human Capital. New York: NBER.

Becker, G. S. (1993). Human capital: A theoretical and empirical analysis with difference to education. (3rd ed.). Chicago: The Chicago University press.

BIT. (1998). Mesure du revenu de l'emploi. Genève: Rapport I de la XVI ieme Conférence Internationale des Statisticiens du Travail.

Blanchflower, D. G. (2000). Self-employment in OECD Countries. Labour Economics, 7(5), 471-505. http://dx.doi.org/10.1016/S0927-5371(00)00011-7

Bourguignon, F., Fournier, M., \& Gurgand, M. (2007). Selection Bias Corrections Based on the Multinomial Logit Model: Monte-Carlo Comparisons. Journal of Economic Surveys, 21(1), 174-205. http://dx.doi.org/10.1111/j.1467-6419.2007.00503.x

Cahuc, P., \& Zylberberg, A. (2001). Le Marché du Travail. Bruxelles: De Boeck Université. (Rue des mines, 39 B-1000).

Cahuc, P., \& Zylberberg, A. (2003). Microéconomie du marché du travail. Paris: La Découverte (Collection Repères).

Card, D. (2001). Estimating the Return to Schooling: Progress on Some Persistent Econometric Problems. Econometrica, 69(5), 1127-1160. http://dx.doi.org/10.1111/1468-0262.00237

D’Amours, M. (2006). Le Travail Indépendant. Québec: Presses de l'Université du Québec.

Debande, O., \& Vandenberghe, V. (2008). Investir dans le capital humain: Comprendre les ressorts d'une décision individuelle et sociale (Eds.), Academia-Bruylant. Belgique: Louvain la Neuve. (Grand Place 29 1348).

DSCN /MINEFI. (1997). Conditions de vie des ménages au Cameroun en 1996. Yaoundé: MINEFI, ECAM I. (Volume II- résultats).

DSCN /MINEFI. (2002).Conditions de vie des populations et profil de pauvreté au Cameroun en 2001. Yaoundé: MINEFI, ECAM II.

Fields, G. S. (2007). Labor Market Policy in Developing Countries: A Selective Review of the Literature and Needs for the Future. Cornell University ILR School: ILR Collection Working Papers.

Fomba Kamga, B. (2008). Contrat de Travail et Fonctionnement du Marché du Travail au Cameroun, Thèse Ph.D en Sciences Economiques non publiée: Université de Yaoundé II, Soa.

Gazier, B. (1992). Economie du travail et de l'emploi. (2nd ed.). Paris: Précis Dalloz.

Gibbons, R., \& Waldman, M. (2004). Task-Specific Human Capital. American Economic Review. 94(2), 203-207. http://dx.doi.org/10.1257/0002828041301579

Gourieroux, C. (1989). Econométrie des variables qualitatives. (2nd éd.). Paris: Economica. 
Goux, D., \& Maurin, E. (1994). Education, expérience et salaire: tendances récentes et évolution de long terme. Economie et Prévision n1, 16, 155-173.

Grasser, B., \& Rose, J. (2000). L'expérience professionnelle: sa définition, son acquisition et son utilisation. Formation emploin, 71, 5-19.

Greene, W. H. (2003). Econometric Analysis. (5th ed.). Prentice-Hall: Upper Saddle River, NJ.

Hatch, N. W., \& Dyer, J. H. (2004). Human capital and learning as a source of sustainable competitive advantage. Strategic Management Journal, 25, 1155-1178. http://dx.doi.org/10.1002/smj.421

Heckman, J. (1976). The Common Structure of Statistical Models of Truncation, Sample Selection and Limited Dependent Variables and a Sample Estimator for Such Models. Annals of Economic and Social Measurement, 5(4), 475-492.

Heckman, J. (1979). Sample Selection Bias as a Specification Error. Econometrica, 47(1), 153-61. http://dx.doi.org/10.2307/1912352

Heckman, J., Layne-Farrar, A., \& Todd, P. (1996). Human Capital Pricing Equations with an Application to Estimating the Effect of Schooling Quality on Earnings. Review of Economics and Statistics, 78(4), 562-610. http://dx.doi.org/10.2307/2109948

Hirata, H., Lautier, B., \& Salama, P. (1998). Les transformations du travail. Revue Tiers-Monde, n154. Paris: PUF.

INS. (2002). Deuxième enquête camerounaise auprès des Ménages: Pauvreté et éducation au Cameroun en 2001. Rapport principal, Novembre.

INS. (2005). Enquête sur l'emploi et le secteur informel au Cameroun (EESI) en 2005. Rapport principal, Décembre.

INS. (2006). Annuaire statistique du Cameroun 2006. Yaoundé: Décembre.

INS. (2008). Annuaire statistique du Cameroun 2008. Yaoundé: Décembre.

INS. (2009). Troisième enquête camerounaise auprès des Ménages: Tendances, profil et déterminants de la pauvreté au Cameroun en 2007. Rapport principal, Juillet.

INSEE. (2006). Les revenus d'activité des indépendants. Collection Références: Juin.

Jarousse, J. P., \& Mingat, A. (1986). Un réexamen du modèle de gains de Mincer. Revue économique. 37(6), 999-1031.

Lemelin, C. (1998), L'économiste et l'éducation. Québec: Presses de l'université de Québec.

Lévy-Garboua, L. (1994). Formation sur le tas et rendement de l'expérience: un modèle de diffusion du savoir. Economie et Prévision, 116, 79-88.

Livingstone, D. W. (1997). The limits of HCT: Expanding knowledge, Informal Learning and Unemployment. Policy Options, July/Aug.

Mallet, L., \& Vernières, M. (1981). L'expérience professionnelle dans les modes de gestion de la main d'œuvre. Travail et emploi, 9, 65-74.

Marchand, O. (1998). Salariat et non-salariat dans une perspective historique. Economie et Statistique, 319, 3-11. http://dx.doi.org/10.3406/estat.1998.2666

Mincer, J. (1974). Schooling, experience and earnings. New York: Columbia University Press for the NBER.

Mincer, J. (1993). Schooling, Experience, and Earnings England. Gregg Revivals, (réédition).

MINEFI/INS. (2000). Annuaire statistique du Cameroun. Yaoundé: Décembre.

OIT. (1998). La mesure du sous-emploi, Rapport de la Seizième conférence internationale des statisticiens du travail. Genève: 6-15 octobre.

Pagès, N. (2008). Hétérogénéité du travail et développement en Côte d'Ivoire: une analyse à partir des dynamiques productives et spatiales. The European Journal of Development Research, 20(1),117-140.

Parent, D. (1996). Survol des contributions théoriques et empiriques liées au capital humain. L'Actualité économique,72(3), 315-356.

Perulli, A. (2003), Étude sur le travail dépendant ou para subordonné (PP. 110). Bruxelles: Parlement européen. 
Psacharopoulos, G. (1994). Returns to investment in education: a global update. World development, 22(9), 1325-1343. http://dx.doi.org/10.1016/0305-750X(94)90007-8

Rouault, D. (2001). Les revenus des indépendants et dirigeants: La valorisation du bagage personnel. Economie et Statistiques, 8(348), 35-59. http://dx.doi.org/10.3406/estat.2001.7424

Roubaud, F. (1994). Le marché du travail à Yaoundé, 1983-1993. La décennie perdue. Tiers-Monde, 35(140), 751-778. http://dx.doi.org/10.3406/tiers.1994.4919

Smith, P. A., \& Metzger, M. R. (1998). The Return to Education: Street Vendors in Mexico. World Development, 26(2), 289-296. http://dx.doi.org/10.1016/S0305-750X(97)10020-1

Spence, M. (1973). Job Market Signalling. Quarterly Journal of Economics, 87, 355-374. http://dx.doi.org/10.2307/1882010

Tafah-Edokat, E. O. (1998). Rates of return to education: a case of Cameroon (Mimeo). University of Yaounde II, Soa: Department of Economics.

Thurow, L. C. (1975). Generating inequality: mechanisms of distribution in the US Economy. New York: Basic Books.

Tsafack Nanfosso, R. A., \& Song Ntamack, S. A. (2005). Child labour in Yaoundé-Cameroon: Some lessons drawn from a survey on children. Journal of Economics and Business, 23(2), 195-215.

Willis, R. (1986). Wage Determinants: a Survey and Reinterpretation of Human Capital Earnings Functions. In Ashanfelter, O., \& Layard, R. (Eds.), Handbook of Labors Economics (vol1, pp. 525-580). Amsterdam: Elsevier Science Publishers BV.

World Bank. (2002). Achieving Education for All by 2015, Simulations Results for 47 Low-Income Countries. Washington D.C.

\section{Notes}

Note 1. Benefit (agricultural, industrial or commercial, noncommercial), wages, remunerations of social agent, dividends, appreciations or composite combination of all these types of remuneration (Rouault, 2001) constitute as many payments as perceive the non salary-earners in exchange of the participation to work.

Note 2. Sample selectivity biases come about because the data used in the estimation are nonrandom. As such, regressions run using individual data omitting unobserved ability are biased because unobserved heterogeneity contaminates the sample.

Note 3. Lee (1983) proposes a generalize method of correcting selections bias into two stages which were introduced by Heckman (1979) in case the distribution of residues follow any kind of law and not only a bivariate law. The problem caused by the multinational logit is that the relation between two probabilities of $\mathrm{m}$ and $\mathrm{n}$ alternatives is independent from the alternatives of the remaining choices It's independent of the remaining alternatives. This is an IIA property (independence of irrelevant alternatives, independence of non pertinent status), which comes from the notion of independent hypothesis and of the heteroscedasticity of errors between the different modalities. This can be verified through Hausman's test. Lee's extended method in case the selection procedure is modeled by a multinational logit, validated by Bourguignon and al (2007).

Note 4. Represents the variability part of activity revenue's explained by the model. Here, $15.75 \%$ of the variability in revenue is explained by age, studies and experience. This measure which doesn't explain the dependent variable can increase but in a fictive manner when we add explanatory variables.

Note 5. Initial cost corresponds to the set of expenses directly linked to education and the opportunity cost incurred as a result of time spent in training which could had been used in generating some amount of revenue.

Note 6. Since 1970s, the applicability of human capital theory's claims for returns to formal education has been thrown into doubt, as school enrolment rates have continued to increase while average incomes have stagnated, unemployment rates have worsened and underemployment of highly schooled people has been recognized as a social problem (see D.W. Livingstone. The limits of HCT: Expanding knowledge, Informal Learning and Unemployment. Policy Options. July/August, 1997). 
Table 1. Variables used to evaluate the benefits of human capital accumulated by non wage-earners

\begin{tabular}{|c|c|}
\hline Variables & Definitions \\
\hline Logarithm of Income & $\begin{array}{l}\text { Nepierian logarithms of the monthly activity income declared takes } \\
\text { account of the real working time declared at the time of the } \\
\text { investigation and not of } 8 \text { hours the official working time per day. }\end{array}$ \\
\hline $\begin{array}{l}\text { Human capital: } \\
\text { Education } \\
\text { Length of studies } \\
\text { Experience in employment } \\
\text { Adolescence }\end{array}$ & $\begin{array}{l}\text {-Level of education-Dummy- } 1=\text { Uneducated; } 2=\text { Primary); } \\
3=\text { Secondary; } 4=\text { Higher education } \\
\text { - Expressed in years } \\
\text { - Expressed in years of Experience in employment } \\
\text { - Gathers two variables' characteristic of adolescence: Employment of } \\
\text { the father-Dummy- } 1=\text { Yes; } 0=\text { No \& Presence in the Dummy- } 1 \\
\text { household = Yes; } 0=\text { No. }\end{array}$ \\
\hline $\begin{array}{l}\text { Others } \\
\text { Individual Characteristics: } \\
\text { Age } \\
\text { Sex } \\
\text { Marital status } \\
\text { Region } \\
\text { Migrant } \\
\text { Urban } \\
\text { Size of Household } \\
\text { Religion } \\
\text { Handicap }\end{array}$ & $\begin{array}{l}\text { - Age expressed in years } \\
\text { - Sex - Dummy - } 1 \text { =Male; } 0=\text { Female }- \\
\text { Matrimonial Status - Dummy }-1=\text { Unmarried (including divorced and } \\
\text { widowed); } 2=\text { Married (polygamous included/understood) } \\
\text { - Region of activity - Dummy - } 1=\text { Coast; } 2=\text { Forest; } 3=\text { Sahel; } \\
4 \text { = Highlands } \\
\text { - Migratory Status - Dummy - } 1=\text { Migrating; } 0=\text { Non Migrating } \\
\text { - Place of residence - Dummy - } 1=\text { Urban; } 0=\text { Rural } \\
\text { - Number of people in the household } \\
\text { - Religious Status - Dummy }-1=\text { Christian; } 2=\text { Others Religions } \\
\text { - Physical Condition of individual - Dummy }-1=\text { Handicapped; } \\
0=\text { Non handicapped }\end{array}$ \\
\hline
\end{tabular}

Table 2. Descriptive statistics of variables used to evaluate the output of the human capital

\begin{tabular}{|c|c|c|}
\hline Variables & Average & Standard deviation \\
\hline Logarithm of Income & 2.7975 & 1.0904 \\
\hline Age & 35.3015 & 15.2371 \\
\hline Male & 0.4461 & 0.4971 \\
\hline Physical condition: & 1.0345 & 0.1824 \\
\hline Marital status: & 0.5067 & 0.4999 \\
\hline Religion: & 0.7190 & 0.4495 \\
\hline Length of studies & 5.2031 & 3.8910 \\
\hline $\begin{array}{r}\text { Uneducated } \\
\text { Primary education } \\
\text { Secondary education } \\
\text { Higher education }\end{array}$ & $\begin{array}{l}0.2318 \\
0.4220 \\
0.3288 \\
0.0174\end{array}$ & $\begin{array}{l}0.4220 \\
0.4939 \\
0.4698 \\
0.1307\end{array}$ \\
\hline Experience in employment & 9.0912 & 10.9776 \\
\hline Place of residence: & 0.7066 & 0.4553 \\
\hline $\begin{array}{r}\text { Coast } \\
\text { Forest } \\
\text { Sahel } \\
\text { Highlands }\end{array}$ & $\begin{array}{l}0.2585 \\
0.2808 \\
0.1862 \\
0.2745\end{array}$ & $\begin{array}{l}0.4378 \\
0.4494 \\
0.3893 \\
0.4463 \\
\end{array}$ \\
\hline Migratory status & 0.5966 & 0.4906 \\
\hline $\begin{array}{cc}\text { Adolescence: } & \begin{array}{r}\text { Employment of the father in adolescence } \\
\text { Absence of the father in adolescence }\end{array} \\
\end{array}$ & $\begin{array}{l}0.7749 \\
0.1138 \\
\end{array}$ & $\begin{array}{l}0.4177 \\
0.3176\end{array}$ \\
\hline
\end{tabular}

Source: Constructed from raw data (EESI, 2005). 
Table 3. Results of estimates resulting from the standard model of Mincer and its corrected form

\begin{tabular}{|c|c|c|c|c|}
\hline & \multicolumn{2}{|c|}{ Ln of Income (Equation1) } & \multicolumn{2}{|c|}{ Ln of Income (Equation 5) } \\
\hline & $\begin{array}{l}\text { Coefficient } \\
\text { (Standard } \\
\text { deviation) }\end{array}$ & t-student & $\begin{array}{l}\text { Coefficient } \\
\text { (Standard } \\
\text { deviation) }\end{array}$ & t-student \\
\hline Constant & $\begin{array}{l}1.9099 * * * \\
(0.0581)\end{array}$ & 32.9 & $\begin{array}{l}0.153 * \\
(0.08844)\end{array}$ & 1.74 \\
\hline Age & $\begin{array}{l}0.0304 * * * \\
(0.0034)\end{array}$ & 9.08 & $\begin{array}{l}0.05953 * * * \\
(0.00356)\end{array}$ & 16.71 \\
\hline Square of age & $\begin{array}{l}-0.00036^{* * *} \\
(0.000042)\end{array}$ & -8.43 & $\begin{array}{l}-0.00067 * * * \\
(0.000045)\end{array}$ & -14.86 \\
\hline $\begin{array}{l}\text { Level of studies, instrumented in } \\
\ln \text { (Returned) corrected }\end{array}$ & $\begin{array}{l}0.07614 * * * \\
(0.0027)\end{array}$ & 27.98 & $\begin{array}{l}0.01632 * \\
(0.009811)\end{array}$ & 1.66 \\
\hline $\begin{array}{l}\text { Square level of studies, instrumented } \\
\text { in } \ln \text { (benefits) corrected }\end{array}$ & & & $\begin{array}{l}0.004917^{* * *} \\
(0.00093)\end{array}$ & 5.31 \\
\hline Experience in employment & $\begin{array}{l}0.0049 * \\
(0.00261)\end{array}$ & 1.89 & $\begin{array}{l}0.0167 * * * \\
(0.0026)\end{array}$ & 6.42 \\
\hline Experience in employment squared & $\begin{array}{l}-0.00011^{*} \\
(0.000061)\end{array}$ & -1.79 & $\begin{array}{l}-0.00029 * * * \\
(0.000060)\end{array}$ & -4.81 \\
\hline $\begin{array}{l}\text { Correction of the participation in the } \\
\text { labor market }\left(\phi_{i}\right)\end{array}$ & & $\begin{array}{l}2.637 * * * \\
(0.1070)\end{array}$ & 24.63 & \\
\hline $\begin{array}{l}\text { F-test (Proba) } \\
\text { R2 adjusted (in \%) } \\
\text { Number of observations }\end{array}$ & $\begin{array}{l}207.36 \\
10.74 \\
10550\end{array}$ & & $\begin{array}{l}248.77 \\
15.75 \\
10550\end{array}$ & \\
\hline
\end{tabular}

Threshold of significativity: $(* * *) 1 \%,\left(^{* *}\right) 5 \%,\left(^{*}\right) 10 \%$. The standard deviations are noted between brackets.

Source: Constructed from raw data (EESI, 2005). 
Appendix: Equation of participation of the non wage-earning persons in the labor market (Results of estimates)

\begin{tabular}{|c|c|c|c|c|}
\hline \multicolumn{3}{|l|}{ Multinomial logistic regression Number of obs $=2252$} & \multicolumn{2}{|c|}{$\begin{array}{r}\text { LR chi2(34) }=10773.90 \\
\text { Prob }>\text { chi2 }=0.0000 \\
\text { Log likelihood }=-18057.078 \\
\text { Pseudo } 22=0.2298 \\
\end{array}$} \\
\hline & Coefficient & $\begin{array}{l}\text { Standard } \\
\text { deviation }\end{array}$ & t-student & $\mathrm{P}>|\mathrm{z}|$ \\
\hline \multicolumn{5}{|c|}{ Non wage-earners } \\
\hline Age & 0.239 & 0.006 & 39.57 & 0.000 \\
\hline Square of age & -0.0026 & 0.00007 & -36.50 & 0.000 \\
\hline Sex & 0.484 & 0.0366 & 13.23 & 0.000 \\
\hline Handicap & -1.080 & 0.082 & -13.17 & 0.000 \\
\hline Household size & -0.035 & 0.0045 & -7.87 & 0.000 \\
\hline Marital status: & -0.0516 & 0.0424 & -1.22 & 0.223 \\
\hline $\begin{array}{r}\text { Higher education } \\
\text { Secondary education } \\
\text { Primary education } \\
\text { Uneducated } \\
\end{array}$ & $\begin{array}{r}0.4587 \\
-0.557 \\
-1.819 \\
- \\
\end{array}$ & $\begin{array}{c}0.062 \\
0.0644 \\
0.108 \\
- \\
\end{array}$ & $\begin{array}{c}7.44 \\
-8.65 \\
-16.86 \\
- \\
\end{array}$ & $\begin{array}{r}0.000 \\
0.000 \\
0.000 \\
- \\
\end{array}$ \\
\hline Migrating & -0.189 & 0.039 & -4.86 & 0.000 \\
\hline Christian & 0.2085 & 0.048 & 4.34 & 0.000 \\
\hline Urban & -1.220 & 0.0528 & -23.11 & 0.000 \\
\hline $\begin{array}{lr}\text { Area of activity: } & \text { Coasta } \\
& \text { Forest } \\
& \text { Sahel } \\
& \text { Highlands } \\
\end{array}$ & $\begin{array}{c}-0.308 \\
-0.419 \\
0.301 \\
- \\
\end{array}$ & $\begin{array}{c}0.0599 \\
0.057 \\
0.066 \\
- \\
\end{array}$ & $\begin{array}{c}-5.14 \\
-7.36 \\
4.55 \\
- \\
\end{array}$ & $\begin{array}{l}0.000 \\
0.000 \\
0.000 \\
- \\
\end{array}$ \\
\hline Condition of adolescence: $\begin{array}{r}\text { Working father } \\
\text { Absence of the father }\end{array}$ & $\begin{array}{c}0.151 \\
-0.238\end{array}$ & $\begin{array}{c}0.055 \\
0.0691\end{array}$ & $\begin{array}{c}2.73 \\
-3.45\end{array}$ & $\begin{array}{l}0.006 \\
0.001\end{array}$ \\
\hline Constant & -1.536 & 0.1606 & -9.56 & 0.000 \\
\hline \multicolumn{5}{|c|}{ Wage-earners } \\
\hline Age & 0.461 & 0.0109 & 42.39 & 0.000 \\
\hline Square of age & -0.0054 & 0.00014 & -38.39 & 0.000 \\
\hline Sex & 1.831 & 0.0487 & 37.62 & 0.000 \\
\hline Handicap & -1.038 & 0.114 & -9.13 & 0.000 \\
\hline Household size & -0.0746 & 0.00624 & -12.00 & 0.000 \\
\hline Marital statuts: & -0.0315 & 0.055 & -0.57 & 0.566 \\
\hline $\begin{array}{r}\text { Higher education } \\
\text { Secondary education } \\
\text { Primary education } \\
\text { Uneducated } \\
\end{array}$ & $\begin{array}{c}1.258 \\
0.986 \\
1.079 \\
- \\
\end{array}$ & $\begin{array}{c}0.102 \\
0.1024 \\
0.1201 \\
- \\
\end{array}$ & $\begin{array}{c}12.37 \\
9.63 \\
8.96 \\
- \\
\end{array}$ & $\begin{array}{c}0.000 \\
0.000 \\
0.000 \\
- \\
\end{array}$ \\
\hline Migrating & 0.092 & 0.052 & 1.77 & 0.076 \\
\hline Christian & 0.2001 & 0.067 & 3.24 & 0.001 \\
\hline Urban & -0.0431 & 0.079 & -0.55 & 0.585 \\
\hline $\begin{array}{r}\text { Coastal } \\
\text { Forest } \\
\text { Sahel } \\
\text { Highlands } \\
\end{array}$ & $\begin{array}{c}-0.298 \\
-0.257 \\
-0.1606 \\
-\end{array}$ & $\begin{array}{l}0.077 \\
0.075 \\
0.091 \\
-\end{array}$ & $\begin{array}{c}-3.84 \\
-3.43 \\
-1.76 \\
-\end{array}$ & $\begin{array}{c}0.000 \\
0.001 \\
0.078 \\
-\end{array}$ \\
\hline $\begin{array}{rr}\text { Condition of adolescence: } & \text { Working father } \\
& \text { Absence of the father } \\
\end{array}$ & $\begin{array}{c}0.0812 \\
-0.1422 \\
\end{array}$ & $\begin{array}{c}0.07041 \\
0.0875 \\
\end{array}$ & $\begin{array}{c}1.15 \\
-1.63 \\
\end{array}$ & $\begin{array}{l}0.249 \\
0.104 \\
\end{array}$ \\
\hline Constant & $\begin{array}{l}-9.184 \\
\end{array}$ & 0.269 & -34.07 & 0.000 \\
\hline
\end{tabular}

Source: Built starting from raw data (EESI, 2005) 